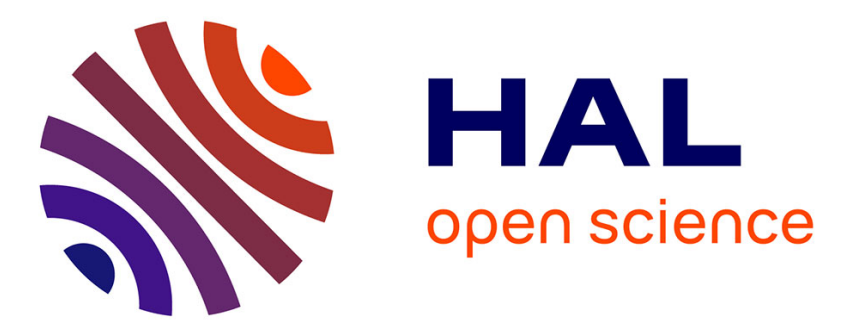

\title{
Using transferrin saturation as a diagnostic criterion for iron deficiency: A systematic review
}

\author{
Patrice Cacoub, Cécile Vandewalle, Katell Peoc'h
}

\section{To cite this version:}

Patrice Cacoub, Cécile Vandewalle, Katell Peoc'h. Using transferrin saturation as a diagnostic criterion for iron deficiency: A systematic review. Critical Reviews in Clinical Laboratory Sciences, 2019, 56 (8), pp.526-532. 10.1080/10408363.2019.1653820 . hal-02303354

\section{HAL Id: hal-02303354 https://hal.sorbonne-universite.fr/hal-02303354}

Submitted on 2 Oct 2019

HAL is a multi-disciplinary open access archive for the deposit and dissemination of scientific research documents, whether they are published or not. The documents may come from teaching and research institutions in France or abroad, or from public or private research centers.
L'archive ouverte pluridisciplinaire HAL, est destinée au dépôt et à la diffusion de documents scientifiques de niveau recherche, publiés ou non, émanant des établissements d'enseignement et de recherche français ou étrangers, des laboratoires publics ou privés. 


\section{Using transferrin saturation as a diagnostic criterion for iron deficiency: a systematic review}

Patrice Cacoub ${ }^{1,2,3,4}$, Cécile Vandewalle ${ }^{5}$, Katell Peoc’h ${ }^{6,7}$

${ }^{1}$ Inflammation-Immunopathology-Biotherapy Department (DHU i2B), UMR 7211, UPMC Université Paris 06, Sorbonne Universités, Paris F-75005, France.

${ }^{2}$ INSERM, UMR_S 959, F-75013, Paris, France.

${ }^{3}$ CNRS, FRE3632, F-75005, Paris, France.

${ }^{4}$ Department of Internal Medicine and Clinical Immunology, AP-HP, Groupe Hospitalier Pitié-Salpêtrière, 83 boulevard de l'hôpital, Paris F-75013, France.

${ }^{5}$ Biodimed Conseils - 11 rue Anatole de la Forge - 75017 Paris - France

${ }^{6}$ Université Paris Diderot, UFR de Médecine Xavier Bichat, Centre de Recherche sur I'Inflammation (CRI), INSERM UMRs 1149, F-75018 Paris, France, équipe Heme, Fer et pathologies inflammatoires.

${ }^{7}$ APHP, HUPNVS, UF de Biochimie Clinique, Hôpital Beaujon, F-91118, Clichy, France.

Corresponding author: Pr Patrice Cacoub, MD, MSc, Department of Internal Medicine and Clinical Immunology, AP-HP, Groupe Hospitalier Pitié-Salpêtrière, 83 boulevard de l'hôpital, Paris F-75013, France. Tel: + 33 (0) 1421780 27; Fax: + 33 (0) 1421780 33; Email: patrice.cacoub@aphp.fr 


\begin{abstract}
Iron deficiency is the most common micronutrient deficiency in the world and represents a major challenge for public health, notably in terms of morbidity and mortality. It remains largely under-diagnosed due to the low level of exploration and the absence of international harmonization for biological tests and thresholds. We performed a systematic review of the literature using PubMed, which allowed us to identify 41 publications within the scope of this review. This analysis shows the benefit of using transferrin saturation in addition to ferritin, in the diagnosis of iron deficiency and even in first-line analysis for patients with chronic inflammatory diseases.
\end{abstract}

Keywords: Iron deficiency, ferritin, transferrin, saturation. 


\section{Introduction}

Iron deficiency (ID) is the most common and widespread deficiency in the world ${ }^{1}$ and represents a significant challenge for public health². Approximately two billion people, or over $30 \%$ of the world population, suffer from anemia principally due to $\mathrm{ID}^{3}$. ID, with or without anemia, is associated with fatigue, altered quality of life, and productivity at work ${ }^{3}$. ID is defined by the presence of an insufficient supply of iron to meet the requirements of the organism ${ }^{2,4}$. Despite the high prevalence, including in developed countries ${ }^{1}$, ID remains under-diagnosed, due to the absence of international harmonization for diagnostic test and thresholds ${ }^{2}$ or the existence of inflammatory disease. When ID is associated with inflammation, the interpretation of serum ferritin usually used to detect it becomes equivocal ${ }^{5}$. This becomes problematic as chronic inflammation is often associated with ID $^{2}$. For example, 37 to $61 \%$ of patients with chronic heart failure (CHF), 24 to 85\% of patients with chronic kidney disease (CKD) and 13 to $90 \%$ of patients with inflammatory bowel disease (IBD) have ID $^{4}$. In these situations, ID can have severe consequences leading to a faster deterioration of clinical signs ${ }^{4}$.

According to the assessment report published by the French National Authority for Health (Haute Autorité de Santé, France) in 2011, diagnosis of ID must rely on serum ferritin levels, and in cases of inflammatory pathologies (e.g. CHF, CKD, IBD), must systematically be associated with transferrin saturation (TSAT) ${ }^{6}$. Ironis principally stored in the organism within ferritin and is present in the circulation as a result of release from macrophages and cell lysis. Transferrin is the primary iron transport protein in the circulation. The TSAT (\%) is the ratio of serum iron concentration ( $\mu \mathrm{mol} / \mathrm{L}) /$ total iron-binding capacity (TIBC; $\mu \mathrm{mol} / \mathrm{L})$, after deduction of the weightadjusted serum concentration of transferrin (g/L). 
To refine the mechanisms leading to ID and optimize patient care, two clinicalbiological representations have been defined - absolute ID and functional ID - each with different origins, different mechanisms and in particular, different biological profiles. Absolute ID is defined as a decrease in the total iron stores in the body (3 to 4 g for a healthy adult). Absolute ID may be the consequence of insufficient iron intake (older adult, malnutrition or malabsorption) or blood loss ${ }^{7}$. Functional ID, also referred to as iron-restricted erythropoiesis, is due to a defect in iron transport from the storage areas (e.g. macrophages, liver), although the total iron stores in the body are normal or even increased ${ }^{5}$. In this situation, despite a correct level of iron stores, the assimilation of iron by erythroid precursor cells is insufficient ${ }^{8}$. The principal cause of functional ID is inflammation, which leads to increased production of hepatic hepcidin, resulting in dysfunction of ferroportin (an iron transporter), and preventing the export of iron from storage areas $^{5}$. A low concentration of serum ferritin $(<100 \mu \mathrm{g} / \mathrm{L})$ and a low TSAT $^{5,7}$ are observed in absolute ID. The functional ID is characterized by a normal or even high serum ferritin concentration and a low TSAT. Therefore, decreased TSAT becomes a particularly performing marker as it does not have similar interpretation limitations as serum ferritin, mainly in inflammatory conditions. This article aims, through a systematic literature review, to assess the benefit of using TSAT as a diagnostic criterion of ID. 


\section{Materials and Methods}

A first literature analysis was performed using PubMed on January $3^{\text {rd }} 2018$ using key terms such as "anemia" and "iron deficiency" (Medical Subject Headings (MeSH)), and selecting consensus conferences, guidelines, meta-analyses, practical recommendations, and reviews. The search was limited to documents in English and French published between January $1^{\text {st }} 1997$ and January $1^{\text {st }} 2018$. Given the large number of publications identified ( $\mathrm{N}=1165)$, this first series was abandoned, and the search criteria were refined for the subsequent analyses.

A second review of the literature was performed on January $11^{\text {th }} 2018$ using key terms such as “anemia” and "iron deficiency” (MeSH), and selecting consensus conferences, recommendations, meta-analyses and practical recommendations. The search was limited to documents in English and French published between January $1^{\text {st }}$ 1997 and January $1^{\text {st }} 2018$. Then a third search was performed using key terms such as “anemia” and "iron deficiency” (MeSH), restricting to reviews in English and French published between January $1^{\text {st }} 2015$ and January $1^{\text {st }} 2018$.

A fourth search was performed using the keywords "anemia", "iron deficiency" (MeSH) and/or "transferrin saturation," selecting consensus conferences, recommendations, meta-analyses, practical recommendations, and reviews. The search was restricted to reviews in English and French with no restriction on the timing of publication.

Finally, a fifth search was performed on April $26^{\text {th }} 2018$ using the keywords "siderophilin" and "iron deficiency," selecting documents in English and French published between January $1^{\text {st }} 1950$ and December $31^{\text {st }} 1980$. This last search sought to take into account the etymological change in the naming of transferrin. 
Information on the ferritin threshold values and/or TSAT used in the diagnosis of ID was extracted from each publication. The majority of publications did not mention the dosing methods used nor the nature of the sample taken (serum or plasma).

\section{Results}

From searches 2, 3, 4 and 5, a total of 835 references $(122+216+297+200)$ were identified using the defined criteria (Figure 1). After verification by two reviewers of titles and/or abstracts, 41 publications were included in the systematic review: six publications from the second literature search, 17 from the third search, 14 from the fourth search and finally, four from the last.

The diagnosis of ID was addressed in some publications $(n=36)$ in the general population $^{3,8-24}$ or specific conditions including pregnancy ${ }^{25}$, older subjects ${ }^{5}$, chronic diseases ${ }^{4}, \mathrm{IBD}^{2,26-29}, \mathrm{CKD}^{30-36}$, and $\mathrm{CHF}^{7,37,38}$. Other publications $(\mathrm{n}=5)$ focused on the levels of one of the markers of ID, either serum ferritin ${ }^{39-41}$ or transferrin ${ }^{42,43}$.

A deeper analysis showed that for the diagnosis of absolute ID, studies used ferritin alone (10/20) or ferritin with TSAT (10/20), whereas no study used TSAT alone (0/20); the corresponding values for the diagnosis of functional ID are 6/24, 18/24 and 0/24 studies (Table 1). Some older studies only addressed the diagnosis of ID (without specifying which type, either absolute or functional) and used ferritin alone (6/21), ferritin with TSAT (13/21) or TSAT alone (3/21). Two of the three studies addressing the diagnosis of ID using TSAT alone were among the oldest of this review ${ }^{22,43}$.

Concerning the thresholds used for the diagnosis of ID, these were defined for serum ferritin, in terms of the presence or absence of inflammation as $<100$ to $300 \mu \mathrm{g} / \mathrm{L}$ or $<16$ to $100 \mu \mathrm{g} / \mathrm{L}$, respectively; and for TSAT as $<15$ to $20 \%$ regardless of inflammatory status. 


\section{Discussion}

ID is a widespread condition often overlooked and under-diagnosed, particularly in patients with chronic inflammation. Based on the review of the literature (835 references, 41 publications analyzed), the diagnosis of ID is mainly based on the concentration of serum ferritin, with variable thresholds in the presence or absence of inflammation, and/or on the TSAT value, with a threshold of $<15$ to $20 \%$ irrespective of inflammatory status.

Several diagnosic methods have been proposed for ID. The analysis of bone marrow (by aspiration or biopsy) is recognized as the "gold standard" for the diagnosis of ID, allowing an estimation of the iron supply in the bone marrow by the Perls staining technique, which reveals hemoseridin ${ }^{16,29,37,44,45}$. This staining method also allows evaluation of the iron stores within macrophages and erythroblasts. For Nielsen et al., the diagnosis is made when $<10 \%$ of erythroblasts (called sideroblasts) are stained using this method ${ }^{46}$. Nevertheless, this technique, which is costly, nonautomated, and uncomfortable for the patient ${ }^{16,45}$, is now only used in cases where the diagnosis is uncertain or when results are contradictory ${ }^{14}$.

Ferritin, the principal protein for iron storage ${ }^{40,47}$, varies in parallel with iron supply in tissues ${ }^{6}$. Serum ferritin concentration, a reflection of the balance between secretion and hepatic clearance, is an indirect method for measuring available iron ${ }^{47,16}$. The World Health Organization has defined the depletion of iron, considered an extreme situation, as serum ferritin levels $<15 \mu \mathrm{g} / \mathrm{L}$ in adults and $<12 \mu \mathrm{g} / \mathrm{L}$ in children ${ }^{48}$. However, ferritin is also an acute phase protein in inflammation, complicating the interpretation of fluctuations in concentration ${ }^{4,36}$. In infection or inflammation, serum ferritin may be "erroneously normal” meaning the values may be consistent with those in the general population, despite a decrease in total iron supply ${ }^{2}$. 
The French National Authority for Health has described numerous other situations in which serum ferritin is increased independently of iron supply levels: hepatic and muscular cytolysis, decompensated diabetes, hyperthyroidism, and certain metabolic syndromes $^{6}$. For serum ferritin, it is appropriate to adapt the threshold for the diagnosis of ID to the inflammatory status of patients, particularly in chronic pathologies. Analysis of analytical methods to determine ferritin concentration in France in 2015 through the national quality control report by the Agence Nationale de Sécurité du Médicament et des Produits de Santé (ANSM) showed variability between methods of 16.5\% (for 993 laboratories). This variability should also be taken into consideration when interpreting these thresholds. The practical recommendations made in $2017^{4}$ proposed a serum ferritin threshold of $100 \mu \mathrm{g} / \mathrm{L}$ in patients with chronic pathologies such as IBD, CK, and CHF, even if some authors consider the level of ferritin does not give a precise indication of the store of iron that can be released or available for erythropoiesis $^{33}$.

TSAT reflects the available quantity of circulating iron and seems to be a better indicator than ferritin of the amount of iron available for bone marrow erythropoiesis and non-erythropoiesis effects. In the blood, iron is mainly bound to a transport protein, transferrin, which can bind one or two atoms of iron ${ }^{6}$, and protect the body from ironinduced reactive oxygen species (ROS) production. The synthesis of transferrin increases when the iron supply in the body is low. The iron-transferrin complex binds to cell membranes via the transferrin receptor, after which, the iron is internalized ${ }^{7}$ by clathrin-mediated endocytosis. In situations of iron homeostasis, $20 \%$ to $45 \%$ of the iron binding sites on transferrin are occupied by ferric ions $\left(\mathrm{Fe}^{3+}\right)$ : the TSAT is equal to the ratio of serum iron/total transferrin fixation capacity ${ }^{40}$. An increase in TSAT is associated with the induction of hepcidin expression, whereas a low TSAT has the 
opposite effect. Therefore, TSAT reflects the total iron availability in the body (deficiency or overload) and the equilibrium between the release of iron from storage areas and its use by bone marrow for erythropoiesis ${ }^{40}$. Historically, TSAT was most used, before methods for measuring serum ferritin levels became established ${ }^{41}$. The study of Bainton et al. ${ }^{22}$ in 1964, showed that the available iron supply in the body exhibited a better correlation with TSAT than with the plasma iron concentration in patients presenting with different degrees of ID and suffering from pathologies mimicking ID. TSAT is considered a good indicator of iron reserves in the bone marrow, and a value below 16\% confirms iron deficient anemia, either absolute or functionnal ${ }^{49}$.

Regardless of the mechanism of ID (absolute or functional), TSAT will be low contrary to serum ferritin (Table 2). These diagnostic properties of TSAT are particularly useful, and even superior to those of serum ferritin, in patients affected by chronic inflammatory pathologies. The association of the two markers, ferritin and TSAT, allows an increase in the respective diagnostic performance of both markers ${ }^{40,7}$. Cappellini et al. ${ }^{4}$ and the French National Authority for Health ${ }^{6}$ advocate for the clinical use of the association of the serum ferritin levels with TSAT in the context of chronic inflammatory pathologies. Besides, TSAT provides prognostic information. In nondialyzed patients with moderate to severe CKD, a reduction in TSAT is associated with an increase in all-cause mortality, independently of serum iron concentration ${ }^{50}$. In patients with CHF, a low TSAT index is independently associated with increased mortality in patients with normal serum iron, whereas a low ferritin concentration is $\operatorname{not}^{49}$.

The recommendations of the European Society of Cardiology published in $2018^{46}$ stipulate that the serum ferritin concentration and TSAT must be measured and 
evaluated together, and ID defined when serum ferritin thresholds below $100 \mu \mathrm{g} / \mathrm{L}$ if TSAT is normal, or from 100 to $299 \mu \mathrm{g} / \mathrm{L}$ when TSAT is below $20 \%$. These threshold values were given in the recommendations of the European Society of Medical Oncology published in $2018^{47}$. TSAT has certain limitations related to the markers used for its calculation ${ }^{40}$. The iron serum concentration varies according to the iron intake from food, leading to large fluctuations throughout the day of $\mathrm{TSAT}^{30}$. Glomerular diseases with proteinuria can lead to a decrease of blood transferrin because of an accelerated leakage of transferrin in the urine, despite a compensatory increase in its production. Excess estrogens (pregnancy, hormonal treatment) can increase the synthesis of transferrin, independently of the iron supply. Hepatocellular lesions affect transferrin concentration. Thus, faced with a suspected ID, the initial outcome should include serum ferritin and measurement of TSAT, in addition to hemoglobin. This type of outcome allows the diagnosis of isolated ID (normal hemoglobin, and ferritin and/or TSAT low), and in case of anemia, to specify the iron levels at the outset ${ }^{4}$. It is interesting to note that these conclusions are in agreement with those obtained for hemochromatosis, or congenital iron overload, where the duration of exposure to a high TSAT is correlated with phenotypic severity, contrary to ferritin, and provides additional information ${ }^{50}$.

This literature review has some limitations. Only references from PubMed were extracted using the indexation, MeSH, limiting the number of older articles (before the 1990s). The references were of heterogeneous quality (population, methodology), taking into account the search date went as far back as 1950. Furthermore, many publications we analyzed are review articles where the authors did not give details of specify sensitivity, specificity or clinical performance of the cut-offs stated. As the present publication review spanned more than 50 years, methods of measurement and 
calibration for ferritin, iron, and transferrin have evolved over this period. The evolution of methods (e.g. turbidimetric, nephelometric and immunochemistry for ferritin radioimmunoassays) constitutes a limitation for comparing the thresholds.

In conclusion, the diagnosis of ID can be complicated to perform in the clinic. The most potent biological parameters to diagnose ID are the measure of serum ferritin levels and a calculation of TSAT. The measure of TSAT appears to be a better reflection of the amount of available iron for bone marrow erythropoiesis than ferritinemia. As TSAT is less prone to fluctuations than ferrtin, particularly in patients suffering from chronic inflammatory diseases, TSAT seems most relevant to diagnose ID.

Conflict of Interest Statement: Patrice Cacoub has received consulting and lecturing fees from Abbvie, AstraZeneca, Bristol-Myers Squibb, Gilead, GlaxoSmithKline, Janssen, Merck Sharp \& Dohme, Servier, and Vifor. Katell Peoc'h has received consulting and lecturing fees from France, Fresenius, Kabi, Masimo, Octapharma, Werfen, Vifor, Siemens Healthineers, Abbott, Brahms, Diasorin and research grants from MSD Avenir and Fujirebio. 


\section{References:}

1. World Health Organisation. Carences en micronutriments (article in French). Available at: http://www.who.int/nutrition/topics/ida/fr/. (Accessed: 3rd April 2018).

2. Dignass, A., Farrag, K. \& Stein, J. Limitations of serum ferritin in diagnosing iron deficiency in inflammatory conditions. Int. J. Chronic Dis. (2018). doi:10.1155/2018/9394060.

3. Peyrin-Biroulet, L., Williet, N. \& Cacoub, P. Guidelines on the diagnosis and treatment of iron deficiency across indications: a systematic review. Am. J. Clin. Nutr. 102, 1585-1594 (2015).

4. Cappellini MD, Comin-Colet J, de Francisco A, Dignass A, Doehner W, Lam CS,et al. Iron deficiency across chronic inflammatory conditions: International expert opinion on definition, diagnosis, and management. Am. J. Hematol. 92, 1068-1078 (2017).

5. Le Petitcorps, H., Monti, A. \& Pautas, É. [Iron deficiency in elderly patients: use of biomarkers] (article in French). Ann. Biol. Clin. (Paris) 73, 639-642 (2015).

6. French National Authority for Health (Haute Autorité de Santé, France). Choix des examens du métabolisme du fer en cas de suspicion de carence en fer Rapport d'évaluation (2011) (article in French). Available at: https://www.hassante.fr/portail/jcms/c_1051506/fr/choix-des-examens-du-metabolisme-du-feren-cas-de-suspicion-de-carence-en-fer-rapport-d-evaluation. (Accessed: 11th April 2018).

7. Cohen-Solal A, Leclercq C, Mebazaa A, De Groote P, Damy T, Isnard R et al. Diagnosis and treatment of iron deficiency in patients with heart failure: expert 
position paper from French cardiologists. Arch. Cardiovasc. Dis. 107, 563-571 (2014).

8. Thomas DW, Hinchliffe RF, Briggs C, Macdougall IC, Littlewood T, Cavill I; British Committee for Standards in Haematology. Guideline for the laboratory diagnosis of functional iron deficiency. Br. J. Haematol. 161, 639-648 (2013).

9. Goddard, A. F., James, M. W., McIntyre, A. S. \& Scott, B. B. Guidelines for the management of iron deficiency anaemia. Gut 60, 1309-1316 (2011).

10. Centers for Disease Control and Prevention (United States). Recommendations to prevent and control iron deficiency in the United States. MMWR Recomm. Rep. 47, 1-29 (1998).

11. Nairz, M., Theurl, I., Wolf, D. \& Weiss, G. Iron deficiency or anemia of inflammation? Differential diagnosis and mechanisms of anemia of inflammation. Wien. Med. Wochenschr. 1946 166, 411-423 (2016).

12. Auerbach, M. \& Adamson, J. W. How we diagnose and treat iron deficiency anemia. Am. J. Hematol. 91, 31-38 (2016).

13. Lopez, A., Cacoub, P., Macdougall, I. C. \& Peyrin-Biroulet, L. Iron deficiency anaemia. Lancet Lond. Engl. 387, 907-916 (2016).

14. Archer, N. M. \& Brugnara, C. Diagnosis of iron-deficient states. Crit. Rev. Clin. Lab. Sci. 52, 256-272 (2015).

15. Camaschella, C. Iron-Deficiency Anemia. N. Engl. J. Med. 373, 485-486 (2015).

16. Pfeiffer, C. M. \& Looker, A. C. Laboratory methodologies for indicators of iron status: strengths, limitations, and analytical challenges. Am. J. Clin. Nutr. 106, 1606S-1614S (2017). 
17. Shander A, Goodnough LT, Javidroozi M, Auerbach M, Carson J, Ershler WB, et al. Iron deficiency anemia - bridging the knowledge and practice gap. Transfus. Med. Rev. 28, 156-166 (2014).

18. Muñoz, M., García-Erce, J. A. \& Remacha, Á. F. Disorders of iron metabolism. Part II: iron deficiency and iron overload. J. Clin. Pathol. 64, 287-296 (2011).

19. Zimmermann, M. B. Methods to assess iron and iodine status. Br. J. Nutr. 99 Suppl 3, S2-9 (2008).

20. Handelman, G. J. \& Levin, N. W. Iron and anemia in human biology: a review of mechanisms. Heart Fail. Rev. 13, 393-404 (2008).

21. Wish, J. B. Assessing iron status: beyond serum ferritin and transferrin saturation. Clin. J. Am. Soc. Nephrol. CJASN 1 Suppl 1, S4-8 (2006).

22. Bainton, D. F. \& Finch, C. A. The diagnosis of iron deficiency anemia. Am. J. Med. 37, 62-70 (1964).

23. Suchdev PS, Namaste SM, Aaron GJ, Raiten DJ, Brown KH, Flores-Ayala R; BRINDA Working Group. Overview of the Biomarkers Reflecting Inflammation and Nutritional Determinants of Anemia (BRINDA) Project. Adv. Nutr. Bethesda Md 7, 349-356 (2016).

24. Nielsen, O. H., Coskun, M. \& Weiss, G. Iron replacement therapy: do we need new guidelines? Curr. Opin. Gastroenterol. 32, 128-135 (2016).

25. Rukuni, R., Knight, M., Murphy, M. F., Roberts, D. \& Stanworth, S. J. Screening for iron deficiency and iron deficiency anaemia in pregnancy: a structured review and gap analysis against UK national screening criteria. BMC Pregnancy Childbirth 15, 269 (2015). 
26. Bou-Fakhredin, R., Halawi, R., Roumi, J. \& Taher, A. Insights into the diagnosis and management of iron deficiency in inflammatory bowel disease. Expert Rev. Hematol. 10, 801-808 (2017).

27. Stein, J., Connor, S., Virgin, G., Ong, D. E. H. \& Pereyra, L. Anemia and iron deficiency in gastrointestinal and liver conditions. World J. Gastroenterol. 22, 7908-7925 (2016).

28. Oustamanolakis, P., Koutroubakis, I. E. \& Kouroumalis, E. A. Diagnosing anemia in inflammatory bowel disease: beyond the established markers. J. Crohns Colitis 5, 381-391 (2011).

29. Bermejo, F. \& García-López, S. A guide to diagnosis of iron deficiency and iron deficiency anemia in digestive diseases. World J. Gastroenterol. 15, 4638-4643 (2009).

30. Bahrainwala, J. \& Berns, J. S. Diagnosis of Iron-Deficiency Anemia in Chronic Kidney Disease. Semin. Nephrol. 36, 94-98 (2016).

31. Agarwal, A. K. Practical approach to the diagnosis and treatment of anemia associated with CKD in elderly. J. Am. Med. Dir. Assoc. 7, S7-S12; quiz S1721 (2006).

32. Bickford, A. K. Evaluation and treatment of iron deficiency in patients with kidney disease. Nutr. Clin. Care Off. Publ. Tufts Univ. 5, 225-230 (2002).

33. Macdougall, I. C. Monitoring of iron status and iron supplementation in patients treated with erythropoietin. Curr. Opin. Nephrol. Hypertens. 3, 620-625 (1994).

34. Gaweda, A. E. Markers of iron status in chronic kidney disease. Hemodial. Int. Int. Symp. Home Hemodial. 21 Suppl 1, S21-S27 (2017). 
35. Madore F, White CT, Foley RN, Barrett BJ, Moist LM, Klarenbach SW, et al. Clinical practice guidelines for assessment and management of iron deficiency. Kidney Int. Suppl. S7-S11 (2008). doi:10.1038/ki.2008.269.

36. Goodnough, L. T. Erythropoietin and iron-restricted erythropoiesis. Exp. Hematol. 35, 167-172 (2007).

37. Konishi, M. \& von Haehling, S. The need for re-defining cut-off values in heart failure: From obesity to iron deficiency. Exp. Gerontol. 87, 1-7 (2017).

38. Tim Goodnough L, Comin-Colet J, Leal-Noval S, Ozawa S, Takere J, Henry D, et al. Management of anemia in patients with congestive heart failure. Am. J. Hematol. 92, 88-93 (2017).

39. Daru J, Colman K, Stanworth SJ, De La Salle B, Wood EM, Pasricha SR. Serum ferritin as an indicator of iron status: what do we need to know? Am. J. Clin. Nutr. 106, 1634S-1639S (2017).

40. Mazza, J., Barr, R. M., McDonald, J. W. \& Valberg, L. S. Usefulness of the serum ferritin concentration in the detection of iron deficiency in a general hospital. Can. Med. Assoc. J. 119, 884-886 (1978).

41. Jacobs, A., Miller, F., Worwood, M., Beamish, M. R. \& Wardrop, C. A. Ferritin in the serum of normal subjects and patients with iron deficiency and iron overload. Br. Med. J. 4, 206-208 (1972).

42. Elsayed, M. E., Sharif, M. U. \& Stack, A. G. Transferrin Saturation: A Body Iron Biomarker. Adv. Clin. Chem. 75, 71-97 (2016).

43. Koerper, M. A. \& Dallman, P. R. Serum iron concentration and transferrin saturation in the diagnosis of iron deficiency in children: normal developmental changes. J. Pediatr. 91, 870-874 (1977). 
44. Grote Beverborg N, Klip IT, Meijers WC, Voors AA, Vegter EL, van der Wal HH, et al. Definition of Iron Deficiency Based on the Gold Standard of Bone Marrow Iron Staining in Heart Failure Patients. Circ Heart Fail. 2018 Feb;11(2):e004519.

45. WHO. Serum ferritin concentrations for the assessment of iron status and iron deficiency in populations. (2011). Available at: http://www.who.int/vmnis/indicators/ferritin/en/. (Accessed: 4th April 2018).

46. McDonagh T, Damy T, Doehner W, Lam CSP, Sindone A, van der Meer P, et al. Screening, diagnosis and treatment of iron deficiency in chronic heart failure: putting the 2016 European Society of Cardiology heart failure guidelines into clinical practice. Eur J Heart Fail. 2018 Dec;20(12):1664-1672.

47. Aapro, M, Beguin Y, Bokemeyer C, Dicato M, Gasco G, Glaspy J et al. Management of Anaemia and Iron Deficiency in Patients With Cancer: ESMO Clinical Practice Guidelines. Annals Oncology 2018; (0): 1-15.

48. Kovesdy, C. P., Estrada, W., Ahmadzadeh, S. \& Kalantar-Zadeh, K. Association of markers of iron stores with outcomes in patients with nondialysis-dependent chronic kidney disease. Clin. J. Am. Soc. Nephrol. CJASN 4, 435-441 (2009).

49. Moliner P, Jankowska EA, van Veldhuisen DJ, Farre N, Rozentryt P, Enjuanes C, et al. Clinical correlates and prognostic impact of impaired iron storage versus impaired iron transport in an international cohort of 1821 patients with chronic heart failure. Int. J. Cardiol. 243, 360-366 (2017).

50. Bardou-Jacquet E, Lainé F, Guggenbuhl P, Morcet J, Jézéquel C, Guyader D, et al. Worse Outcomes of Patients With HFE Hemochromatosis With Persistent Increases in Transferrin Saturation During Maintenance Therapy. Clin Gastroenterol Hepatol. 2017 Oct;15(10):1620-1627. 
Figure 1. Flow chart of the selection of publications for the literature review.

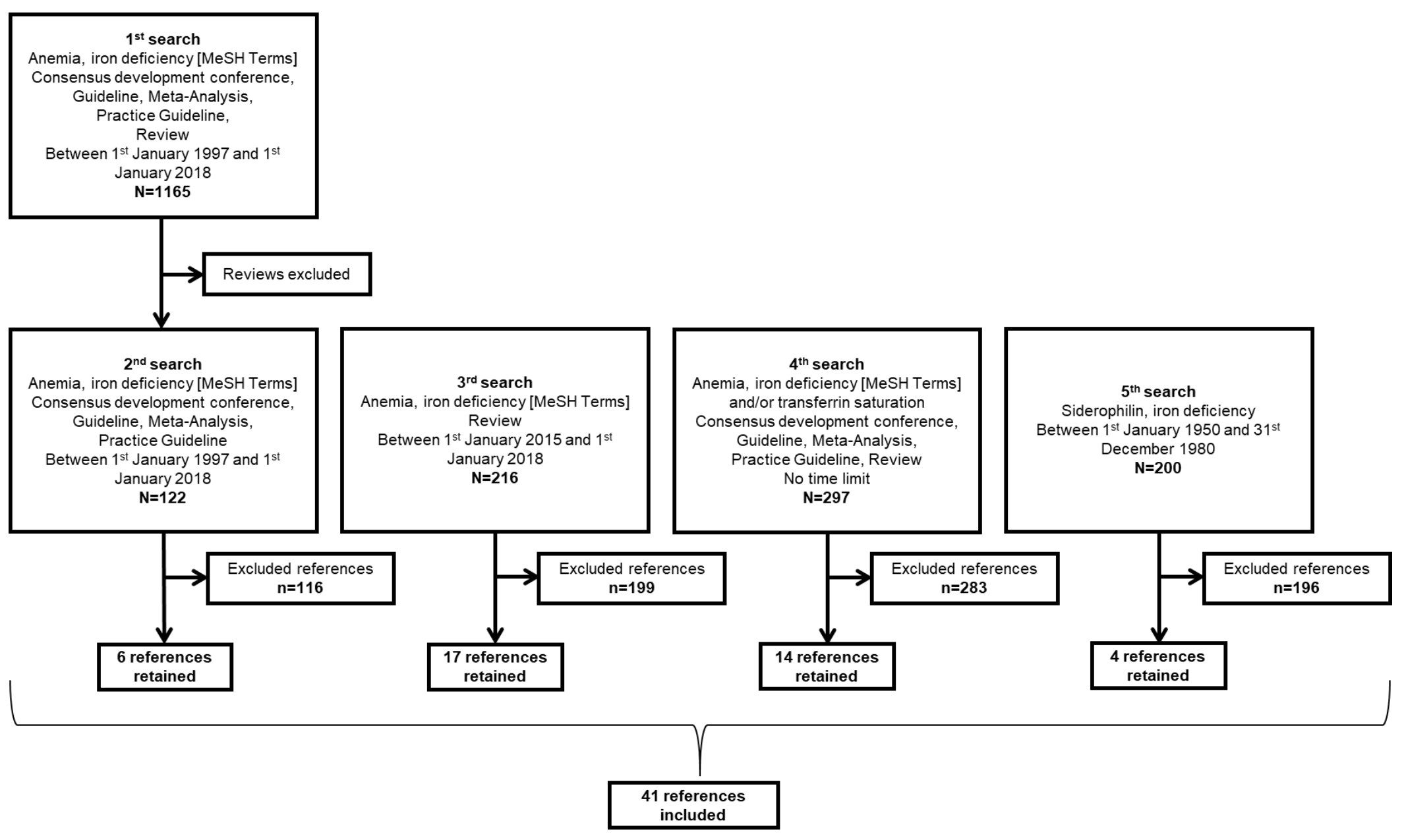


Table 1. Principal publications assessing the diagnostic thresholds of ferritin and TSAT for iron deficiency.

\begin{tabular}{|c|c|c|c|c|c|}
\hline Author, year & Publication type & Population studied & Pathological context & Serum ferritin & TSAT \\
\hline Dignass et al., 2018 ${ }^{2}$ & European consensus & P & $\begin{array}{l}\text { Iron deficiency } \\
\text { Absence of inflammation } \\
\text { Presence of inflammation } \\
\text { Chronic illness anemia }\end{array}$ & $\begin{array}{l}<30 \mu \mathrm{g} / \mathrm{L} \\
<100 \mu \mathrm{g} / \mathrm{L} \\
>100 \mu \mathrm{g} / \mathrm{L}\end{array}$ & $\begin{array}{l}- \\
- \\
<20 \%\end{array}$ \\
\hline Bou-Fakhredin et al., $2017^{26}$ & Review & IBD & Iron deficiency & $\begin{array}{l}<100 \mu \mathrm{g} / \mathrm{L} \\
\text { Si } 100-300 \mu \mathrm{g} / \mathrm{L}\end{array}$ & $\begin{array}{l}- \\
\text { TSAT }<20 \%\end{array}$ \\
\hline Cappellini et al., $2017^{4}$ & $\begin{array}{l}\text { International } \\
\text { recommendations }\end{array}$ & Chronic diseases (CHF, CKF, IBD) & Iron deficiency independent of anemia & $\begin{array}{l}<100 \mu \mathrm{g} / \mathrm{L} \\
100-300 \mu \mathrm{g} / \mathrm{L}\end{array}$ & $\begin{array}{l}\text { TSAT }<20 \% \\
\text { TSAT }<20 \%\end{array}$ \\
\hline Daru et al., $\mathbf{2 0 1 7}^{39}$ & Review & Patients with or without inflammation & Iron deficiency & $<30 \mu \mathrm{g} / \mathrm{L}$ & - \\
\hline Gaweda, $\mathbf{2 0 1 7}^{34}$ & Review & CKD & $\begin{array}{l}\text { Iron deficiency in ND } \\
\text { Iron deficiency in HD }\end{array}$ & $\begin{array}{l}<100 \mathrm{ng} / \mathrm{mL} \\
<200 \mathrm{ng} / \mathrm{mL}\end{array}$ & $\begin{array}{l}<20 \% \\
<20 \%\end{array}$ \\
\hline Goodnough et al., $2017^{41}$ & Review & CHF & Iron deficiency & $<300 \mathrm{ng} / \mathrm{mL}$ & $<20 \%$ \\
\hline Konishi et al., $\mathbf{2 0 1 7}^{37}$ & Review & CHF & Absolute iron deficiency & $\begin{array}{l}<100 \mu \mathrm{g} / \mathrm{L} \\
<300 \mu \mathrm{g} / \mathrm{L}\end{array}$ & $\begin{array}{l}- \\
<20 \% \\
\end{array}$ \\
\hline Pfeiffer et al., $2017^{16}$ & Review & Patients with or without inflammation & $\begin{array}{l}\text { Iron-deficient anemia } \\
\text { Chronic diseases anemia }\end{array}$ & $\begin{array}{l}\text { Decreased } \\
\text { Normal or } \\
\text { increased }\end{array}$ & $\begin{array}{l}\text { Decreased } \\
\text { Decreased }\end{array}$ \\
\hline Peyrin-Biroulet et al., $2015^{3}$ & Review & $\begin{array}{l}\text { Healthy subject and patient (adults; } \\
\text { children) }\end{array}$ & $\begin{array}{l}\text { Absolute iron deficiency } \\
\text { Functional iron deficiency }\end{array}$ & $\begin{array}{l}<100 \mu \mathrm{g} / \mathrm{L} \\
>100 \mu \mathrm{g} / \mathrm{L}\end{array}$ & $\begin{array}{l}<20 \% \\
<20 \% \\
\end{array}$ \\
\hline Auerbach et al., 2016 ${ }^{12}$ & Review & - & Iron deficiency & $<15-25 \mathrm{ng} / \mathrm{mL}$ & $<20 \%$ \\
\hline Bahrainwala et al., $\mathbf{2 0 1 6}^{30}$ & Review & CKD & $\begin{array}{l}\text { Iron-deficient anemia, pre-dialysis or PD } \\
\text { Iron-deficient anemia, HD }\end{array}$ & $\begin{array}{l}<100 \mathrm{ng} / \mathrm{mL} \\
<200 \mathrm{ng} / \mathrm{mL}\end{array}$ & $<20 \%$ \\
\hline Elsayed et al., 2016 ${ }^{42}$ & Review & - & Iron deficiency & - & $<20 \%$ \\
\hline Lopez et al., $2^{2016^{13}}$ & Review & - & $\begin{array}{l}\text { Iron deficiency } \\
\text { Iron deficiency with inflammation } \\
\text { Iron deficiency in ND } \\
\text { Iron deficiency in HD }\end{array}$ & $\begin{array}{l}<15 \mu \mathrm{g} / \mathrm{L} \\
<50 \mu \mathrm{g} / \mathrm{L} \\
<100 \mu \mathrm{g} / \mathrm{L} \\
<200 \mu \mathrm{g} / \mathrm{L}\end{array}$ & $\begin{array}{l}<16 \% \\
<20 \%\end{array}$ \\
\hline Nairz et al., 2016 ${ }^{11}$ & Review & - & Iron-deficient anemia & $<30 \mathrm{ng} / \mathrm{mL}$ & $<16 \%$ \\
\hline Nielsen et al., $\mathbf{2 0 1 6}^{24}$ & Review & With or without chronic diseases & $\begin{array}{l}\text { Iron deficiency without inflammation } \\
\text { Iron deficiency with inflammation }\end{array}$ & $\begin{array}{l}<30 \mu \mathrm{g} / \mathrm{L} \\
<100 \mu \mathrm{g} / \mathrm{L}\end{array}$ & $\begin{array}{l}<16 \% \\
<20 \%\end{array}$ \\
\hline Stein et al., $\mathbf{2 0 1 6}^{27}$ & Review & Gastrointestinal and renal diseases & $\begin{array}{l}\text { Iron deficiency without inflammation } \\
\text { Iron deficiency with inflammation }\end{array}$ & $\begin{array}{l}<30 \mathrm{ng} / \mathrm{mL} \\
<100 \mathrm{ng} / \mathrm{mL}\end{array}$ & $\begin{array}{l}<20 \% \\
<20 \% \\
\end{array}$ \\
\hline Suchdev et al., $2016^{23}$ & $\begin{array}{l}\text { Epidemiological } \\
\text { study }\end{array}$ & Patients with iron deficiency & $\begin{array}{l}\text { Iron deficiency, with or without } \\
\text { inflammation }\end{array}$ & $<30 \mu \mathrm{g} / \mathrm{L}$ & - \\
\hline Archer et al., 2015 & Review & Patients with iron deficiency & Iron deficiency & $<12 \mu \mathrm{g} / \mathrm{L}$ & - \\
\hline
\end{tabular}




\begin{tabular}{|c|l|l|l|l|l|}
\hline Author, year & Publication type & Population studied & Pathological context & Serum ferritin & TSAT \\
\hline & & & $\begin{array}{l}\text { Iron deficiency in ND } \\
\text { Iron deficiency in HD }\end{array}$ & $\begin{array}{l}<100 \mu g / L \\
<200 \mu g / L\end{array}$ \\
\hline
\end{tabular}


Table 1 (cont.). Principal publications assessing the diagnostic thresholds of ferritin and TSAT for iron deficiency.

\begin{tabular}{|c|c|c|c|c|c|}
\hline Author, year & Publication type & Population studied & $\begin{array}{r}\text { Pathological context } \\
\end{array}$ & Serum ferritin & TSAT \\
\hline Camaschella, $\mathbf{2 0 1 5}^{15}$ & Review & 2 & $\begin{array}{l}\text { Iron deficiency } \\
\text { Functional iron deficiency } \\
\text { Iron deficient anemia } \\
\text { Iron deficiency with inflammation } \\
\text { Iron deficiency, CHF or CKF } \\
\end{array}$ & $\begin{array}{l}<30 \mu \mathrm{g} / \mathrm{L} \\
\text { Normal } \\
\\
<10 \mu \mathrm{g} / \mathrm{L} \\
<100 \mu \mathrm{g} / \mathrm{L} \\
<300 \mu \mathrm{g} / \mathrm{L} \\
\end{array}$ & $\begin{array}{l}<16 \% \\
\text { Low - } \\
\text { normal } \\
<16 \% \\
<30 \% \\
\end{array}$ \\
\hline Le Petitcorps et al., $2015^{5}$ & Review & Older subject & $\begin{array}{l}\text { Functional iron deficiency } \\
\text { Absolute iron deficiency }\end{array}$ & $\begin{array}{l}\text { Normal or } \\
\text { increased } \\
<50-100 \mu \mathrm{g} / \mathrm{L}\end{array}$ & $\begin{array}{l}<20 \% \\
<20 \%\end{array}$ \\
\hline Rukuni et al., $2015^{25}$ & Review & Pregnant women & Iron deficiency & $<15 \mu \mathrm{g} / \mathrm{L}$ & - \\
\hline Cohen-Solal et al., 2014 & French expert cardiologists & CHF & $\begin{array}{l}\text { Absolute iron deficiency } \\
\text { Functional iron deficiency }\end{array}$ & $\begin{array}{l}<100 \mu \mathrm{g} / \mathrm{L} \\
100-299 \mu \mathrm{g} / \mathrm{L}\end{array}$ & $\begin{array}{l}- \\
<20 \%\end{array}$ \\
\hline Shander et al., 2014 ${ }^{17}$ & Review & Anemic patients & $\begin{array}{l}\text { Iron deficient anemia } \\
\text { Inflammatory anemia }\end{array}$ & $\begin{array}{l}<30 \mathrm{ng} / \mathrm{mL} \\
<200 \mathrm{ng} / \mathrm{mL}\end{array}$ & $\begin{array}{l}<20 \% \\
<15 \%\end{array}$ \\
\hline Thomas et al., $2013^{8}$ & English recommendations & CKD & $\begin{array}{l}\text { Iron deficiency in ND } \\
\text { Iron deficiency in HD }\end{array}$ & $\begin{array}{l}<100 \mu \mathrm{g} / \mathrm{L} \\
<200 \mu \mathrm{g} / \mathrm{L}\end{array}$ & $\begin{array}{ll}- \\
-\end{array}$ \\
\hline Goddard et al., 2011 ${ }^{9}$ & English recommendations & - & $\begin{array}{l}\text { Iron deficiency without inflammatory pathology } \\
\text { Iron deficiency with inflammatory pathology }\end{array}$ & $\begin{array}{l}12-15 \mu \mathrm{g} / \mathrm{L} \\
<50 \mu \mathrm{g} / \mathrm{L}\end{array}$ & $\begin{array}{ll}- \\
-\end{array}$ \\
\hline Muñoz et al., $\mathbf{2 0 1 1}^{18}$ & Review & According to inflammatory status & $\begin{array}{l}\text { No inflammation: Absolute iron deficiency } \\
\text { With inflammation: } \\
\text { - Absolute iron deficiency } \\
\text { - Functional iron deficiency }\end{array}$ & $\begin{array}{l}<15-30 \mu \mathrm{g} / \mathrm{L} \\
<100 \mathrm{ng} / \mathrm{mL} \\
>100 \mathrm{ng} / \mathrm{mL}\end{array}$ & $\begin{array}{l}- \\
<20 \% \\
<20 \% \\
\end{array}$ \\
\hline Oustamanolakis et al., $\mathbf{2 0 1 1}^{28}$ & Review & IBD & $\begin{array}{l}\text { Iron deficiency without inflammation } \\
\text { Iron deficiency with inflammation } \\
\text { Chronic diseases anemia }\end{array}$ & $\begin{array}{l}<30 \mu \mathrm{g} / \mathrm{L} \\
<100 \mu \mathrm{g} / \mathrm{L} \\
>100 \mu \mathrm{g} / \mathrm{L}\end{array}$ & $\begin{array}{l}<16 \% \\
<16 \% \\
<16 \%\end{array}$ \\
\hline
\end{tabular}


Table 1 (cont.). Principal publications assessing the diagnostic thresholds of ferritin and TSAT for iron deficiency.

\begin{tabular}{|c|c|c|c|c|c|}
\hline Author, year & Publication type & Population studied & Pathological context & Serum ferritin & TSAT \\
\hline Bermejo et al., 2009 ${ }^{29}$ & Review & Digestive diseases & $\begin{array}{l}\text { Iron deficiency, without inflammation } \\
\text { Iron deficiency, with inflammation }\end{array}$ & $\begin{array}{l}<30 \mathrm{ng} / \mathrm{L} \\
<100 \mathrm{ng} / \mathrm{mL}\end{array}$ & $<20 \%$ \\
\hline Handelman et al., $\mathbf{2 0 0 8}^{20}$ & Review & According to the anemia type & $\begin{array}{l}\text { Iron deficiency } \\
\text { Iron deficiency in CKF }\end{array}$ & $\begin{array}{l}<12 \mu \mathrm{g} / \mathrm{L} \\
<200 \mu \mathrm{g} / \mathrm{L}\end{array}$ & $\begin{array}{l}<10 \% \\
<20-50 \%\end{array}$ \\
\hline Madore et al., $\mathbf{2 0 0 8}^{35}$ & Recommendations & CKD & $\begin{array}{l}\text { Iron deficiency in ND without ESA } \\
\text { Iron deficiency in ND and DP receiving ESA } \\
\text { Iron deficiency in HD receiving ESA }\end{array}$ & $\begin{array}{l}<100 \mathrm{ng} / \mathrm{mL} \\
<100 \mathrm{ng} / \mathrm{mL} \\
<200 \mathrm{ng} / \mathrm{mL}\end{array}$ & $\begin{array}{l}<20 \% \\
<20 \% \\
<20 \%\end{array}$ \\
\hline Zimmermann, 2008 $^{19}$ & Review & Healthy adults & Iron deficiency & $<15 \mu \mathrm{g} / \mathrm{L}$ & $<15 \%$ \\
\hline Goodnough et al., $2007^{36}$ & Review & Patients receiving EPO & $\begin{array}{l}\text { Iron deficiency in anemic patient } \\
\text { Iron deficiency in dialyzed patient }\end{array}$ & $\begin{array}{l}<30-40 \mu \mathrm{g} / \mathrm{L} \\
<200 \mu \mathrm{g} / \mathrm{L} \\
<400 \mu \mathrm{g} / \mathrm{L}\end{array}$ & $\begin{array}{l}- \\
- \\
<20 \%\end{array}$ \\
\hline Agarwal, 2006 ${ }^{31}$ & Review & CKD & Iron deficiency & $<100 \mathrm{ng} / \mathrm{mL}$ & $<20 \%$ \\
\hline Wish, 2006 ${ }^{21}$ & Review & CKD & $\begin{array}{l}\text { Absolute iron deficiency } \\
\text { Functional iron deficiency }\end{array}$ & $\begin{array}{l}<100 \mathrm{ng} / \mathrm{mL} \\
\text { Normal or } \\
\text { increased }\end{array}$ & $\begin{array}{l}<20 \% \\
<20 \%\end{array}$ \\
\hline CDC, 1998 $^{10}$ & $\begin{array}{l}\text { American } \\
\text { recommendations }\end{array}$ & $\begin{array}{l}\text { Children (>6 months), adolescents, } \\
\text { pregnant women of childbearing } \\
\text { potential }\end{array}$ & Iron deficiency & $<15 \mu \mathrm{g} / \mathrm{L}$ & $<16 \%$ \\
\hline Bickford, 2002 & Review & CKD & Iron deficiency & $<100 \mathrm{ng} / \mathrm{mL}$ & $<20 \%$ \\
\hline Macdougall, 1994 ${ }^{33}$ & Review & Patients with EPO & Iron deficiency & $<100 \mu \mathrm{g} / \mathrm{L}$ & $<20 \%$ \\
\hline Koerper et al., $1977^{43}$ & Threshold analysis & Healthy children & - & - & $<16 \%$ \\
\hline Jacobs et al., 1972 ${ }^{41}$ & Review e & $\begin{array}{l}\text { Healthy subjects, iron deficient anemia } \\
\text { and iron overload }\end{array}$ & Iron deficiency & $<10 \mathrm{ng} / \mathrm{mL}$ & $<16 \%$ \\
\hline Mazza et al., $\mathbf{1 9 7 8}^{40}$ & $\begin{array}{l}\text { Clinical validation of serum } \\
\text { iron and TSAT }\end{array}$ & Patients having had a myelogram & Iron deficiency & $<18 \mathrm{ng} / \mathrm{mL}$ & $<20 \%$ \\
\hline Bainton et al., $1964^{22}$ & $\begin{array}{l}\text { Clinical validation of iron } \\
\text { deficiency criteria }\end{array}$ & $\begin{array}{l}\text { Patients with iron deficiency or diseases } \\
\text { mimicking iron deficiency }\end{array}$ & Iron deficient anemia & - & $<16 \%$ \\
\hline
\end{tabular}

TSAT, transferrin saturation index; ESA, erythropoiesis-stimulating agent; CKD, chronic kidney disease; PD, peritoneal dialysis; EPO, erythropoietin; CHF, chronic heart failure; CKF, chronic kidney failure; IBD, inflammatory bowel disease; HD, hemodialysis; ND; non-dialyzed. 
Table 2. Variations in the transferrin saturation index based on total iron availability

\begin{tabular}{|l|c|c|c|c|}
\hline & $\begin{array}{c}\text { Serum iron } \\
\text { concentration }\end{array}$ & Transferrin & $\begin{array}{c}\text { Transferrin } \\
\text { saturation }\end{array}$ & Ferritinemia \\
\hline Absolute iron & Decreased & Increased & Decreased & Decreased \\
\hline $\begin{array}{l}\text { Functional iron } \\
\text { deficiency }\end{array}$ & Normal or increased & Decreased & Decreased & Normal or increased \\
\hline
\end{tabular}

